\begin{tabular}{|c} 
Ambiente \& Água - An Interdisciplinary Journal of Applied Science \\
ISSN 1980-993X - doi:10.4136/1980-993X \\
www.ambi-agua.net \\
E-mail: ambi.agua@gmail.com
\end{tabular}

\title{
Sustainable access to safe drinking water: fundamental human right in the international and national scene
}

\author{
doi:10.4136/ambi-agua.2037
}

\author{
Received: 10 Nov. 2016; Accepted: 29 Aug. 2017
}

\section{Celso Maran de Oliveira}

Universidade Federal de São Carlos (UFSCar), São Carlos, SP, Brasil

Departamento de Ciências Ambientais. E-mail: celmaran@gmail.com

\begin{abstract}
Access to potable water is absolutely essential to the maintenance of life, as well as to provide regular exercise of other human rights. The lack of access to water in sufficient quantity or access to non-potable water may cause serious and irreparable damage to people. This paper investigates the evolution of international and national recognition of this fundamental human right, whether implicit or explicit. This was accomplished by the study of international human rights treaties, bibliographic information on water resources and their corresponding legal systems, national and international. The results suggest that sustainable access to drinking water is a fundamental human right in the context of international relations and the State. Further, even without explicitly stating this right in the Constitution of 1988, Brazil has incorporated the main international provisions on the subject, but this right must be acknowledged according to the principles of non-typical fundamental rights and the dignity of the human person. This right should be universally guaranteed by the Government in sufficient quantity and quality, regardless of the economic resources of individuals.
\end{abstract}

Keywords: human right, right to water, sustainability.

\section{Acesso sustentável à água potável: direito humano fundamental no cenário internacional e nacional}

\section{RESUMO}

O acesso à água potável é absolutamente fundamental para a manutenção da vida, além de propiciar o regular exercício dos demais direitos humanos. A falta de acesso à água em quantidade suficiente ou o acesso à água não potável causam sérios e irremediáveis danos às pessoas. Este trabalho tem por objetivo geral investigar a evolução internacional e nacional no reconhecimento desse direito humano fundamental, sejam previsões implícitas ou explícitas sobre o assunto. $\mathrm{O}$ método utilizado foi o acesso aos tratados internacionais sobre direitos humanos, acervo bibliográfico a respeito dos recursos hídricos e seu ordenamento jurídico correspondente, internacional e nacional. Como principais resultados encontrados podem-se destacar que o acesso sustentável à água potável é um direito humano fundamental no âmbito das relações internacionais e no Estado brasileiro; que o Brasil incorporou as principais disposições internacionais a respeito do tema, porém sem fazer constar explicitamente na Magna Carta de 1988 o acesso à água potável como direito humano fundamental, mesmo assim deve ser reconhecido diante dos princípios da não tipicidade dos direitos fundamentais e da dignidade da pessoa humana; que esse direito deve ser garantido pelo poder público em 
quantidade suficiente e qualidade adequada de modo universal e sem que questões econômicas sejam obstáculos à sua efetivação.

Palavras-chave: direito à água, direito humano, sustentabilidade.

\section{INTRODUCTION}

Water is a natural resource that is essential for the maintenance of life. It is abundant, since it covers about two thirds of the Earth surface. However, 97.4\% of the water on Earth is saltwater and only $2.6 \%$ is freshwater. Of this percentage of freshwater, the greatest problem is accessibility, since polar ice caps and glaciers account for $76.4 \%$ of the total, and the remainder is located deep in the earth or exists in the form of humidity. Only $0.3 \%$ of all freshwaters (Bicudo et al., 2010, p. 5) are easily accessed in the form of surface waters, such as rivers and lakes.

The availability of easily accessed freshwater on the planet is therefore limited to a small percentage of total water, and demands for that water have increased exponentially. Further, a significant portion of water use relies upon unsustainable practices, which results in a still larger decrease of available freshwater due to poor quality (Gleick, 2000; Tundisi, 2008; Oliveira and Amarante Junior, 2009). For these reasons, the current worldwide water shortage is a reality for an increasing number of countries influencing the fundamental rights of individuals, both directly and indirectly. Since water resources are not inexhaustible, national public policies must be created to manage their use, acknowledging public quality and economical valuation.

Many countries have faced serious situations of lack of sufficient water for the essential demands of their populations (Cortes et al., 2015), and many others with sufficient water have insufficient drinking water. Both the lack of water overall and the lack of sufficient drinking water are violations of fundamental human rights, since lack of access to drinking water impairs all other fundamental human rights.

The Latin American and Caribbean regions have abundant water resources. The regions concentrate nearly one third of the world's water resources, but their populations amount to only $6 \%$ and their terrestrial surfaces to only $13 \%$ of the world total. The mean availability of water per inhabitant is about $22,000 \mathrm{~m}^{3}$ per inhabitant per year, contrasting with mean worldwide levels slightly above 6,000 (Willaarts et al., 2014, p. 29).

Contrasting this to Brazil, there are twelve hydrographic regions, representing $12 \%$ of the world's freshwater (Galli and Abe, 2010). The estimate of water availability, based on a guarantee of $95 \%$, "is about $12,000 \mathrm{~m}^{3} / \mathrm{s}$ or $22 \%$ of the mean discharge, excluding the contribution of the Amazon basin" (ANA, 2016, p. 23). it is estimated that the total consumption demand for Brazil is $2,275.07 \mathrm{~m}^{3} / \mathrm{s}$, when the harvested discharge is considered (ANA, 2016, p. 33). Irrigation was responsible for the largest harvest (55\% of the total), followed by urban human supply (22\%), industries (15\%), animal production (6\%), and rural human supply (2\%) (ANA, 2016, p. 33). With regard to Brazilian cities, 47\% are supplied exclusively by surface springs, $39 \%$ by subterranean waters, and $14 \%$ by mixed supply (ANA, 2010, p. 34).

On a global level, the availability of water resources in Brazil is less critical than in other countries. The availability of water per inhabitant in Brazil indicates a comfortable situation compared to other countries. The average water availability of rivers in the Brazilian territory is $168,790 \mathrm{~m}^{3} / \mathrm{s}$. When considering the discharge in the Amazon basin area, only within the Brazilian territory, total water availability reaches $257,790 \mathrm{~m}^{3} / \mathrm{s}$ (Tucci et al., 2001, p. 34). Data from the water budget reveal a large hydrological diversity in the Brazilian territory. While there is apparent sufficiency of water in Brazil, there is a non-isonomic spatial distribution of water within the territory. The unequal spatial distribution contributed to the crisis of drinking water supply in several regions of the country, mainly in the large urban centers. 
According to data from the National Information System on Sanitation (SNIS), in 2014 the number of people served by water networks amounted to 156.4 million inhabitants, corresponding to $97.3 \%$ living in urban areas of Brazilian cities. It is worth highlighting the Southern, Southeastern, and Mid-Western regions, where mean indices are 97.3\%, 96.8\% and $96.7 \%$, respectively (Brasil, 2016, p. 1). Average water consumption in Brazil equals 162.0 liters per inhabitant per day. In 2014, consumption presented a regional variation from 118.9 1/hab/day in the Northeast to 187.9 1/hab/day in the Southeast (Brasil, 2016, p. 1).

Brazil has good amount of freshwater in relation to national demands (Augusto et al., 2012), but has an unequal distribution in its regions (Tundisi, 2008). However, the available freshwater is not always water of good quality, due to inadequate treatment. Water quality can be assessed by several parameters that measure physical, chemical, and biological characteristics. Ordinance 2914/2011 of the Ministry of Health determines procedures and responsibilities related to the control and monitoring of water quality for human consumption, and defines water potability by recommending the analysis of physical, chemical, and microbiological parameters such as a) Physical: color, turbidity - for post-filtration or predisinfection water; taste and odor; temperature; and radioactivity. b) Chemical: $\mathrm{pH}$; chloramines; chlorine dioxide; free residual chlorine; fluoride; and secondary disinfection products. c) Microbiological: total coliforms, Escherichia coli, cyanobacteria, and cyanotoxins. The referenced parameters, expressed in the Annexes of Ordinance 2914/2011 of the Ministry of Health, must be met by the water supply system in order to assure the quality and safety of water for human consumption.

Access to drinking water causes direct and indirect impacts to the quality of life in the form of improvement in the life conditions and health benefits such as disease control, improvement of economic productivity, education, economy, comfort and well-being, recreation, and personal valuation of the population. According to Razzolini and Günther $(2008$, p. 3), the "supply of water of good quality and in enough quantity is of vital importance to promote adequate sanitary conditions, protect the health of the population and foster socioeconomic development".

It is considered that a person has access to water when he or she can reach a determined source of water supply up to $1 \mathrm{~km}$ distant in a maximum time of 30 minutes. This water source must be sufficient to provide at least an average of 20 liters of water per inhabitant per day, which can be considered a "high" level in the degree of harmful effects to health (Howard and Bartram, 2003). The accessed water should be potable. When situations are out of these spatial, temporal, and quality parameters, the non-access to water must be recognized, which can incur hazards. There are several problems related to the lack of access to drinking water, mainly related to public and environmental health. Feachem et al. (1983) point out five classes of diseases related to water: a) related to lack of personal and domestic hygiene, as a result of the non-access or due to deficient supply; b) caused by contact with water; c) transmitted by aquatic vectors; d) disseminated by water; e) transmitted through water.

Sustainable access to drinking water is recognized as a fundamental human right as it is essential to human life. The efforts of the United Nations that have gradually brought about this recognition. Brazil, as a member of the United Nations, is promoting changes in its legal system aiming to accord sustainable access to drinking water with the status of a fundamental human right, which will be analyzed throughout this study, both in relation to agreements under the aegis of the United Nations and in the evolution of Brazilian law.

Through the evaluation of national and international legal texts, official studies on freshwaters, and specialized literature on the theme, the efforts of the United Nations for the recognition of the access to drinking water as a human right in several international acts will be demonstrated, with the aim of making these services a direct obligation of sovereign States. The international agreements reflect on national constitutional law and, although protection for 
the right of sustainable access to drinking water is not explicitly stated in the Brazilian Constitution, the Brazilian State must guarantee its universal access.

The present research will identify infra-constitutional norms where it is possible to identify the influence of international legal texts and, consequently, the recognition in Brazil of access to drinking water as a fundamental human right. It will then discuss the principle of non-legal typification of the fundamental human rights and of the respect for human dignity to clarify the fact of its express mention in the Constitution, but with the recognition of this fundamental right.

\section{MATERIAL AND METHODS}

The research was carried out using a hermeneutic approach, with a survey and analysis of data from the United Nations regarding official reports on worldwide water availability, documents of the Brazilian government regarding access to drinking water, as well as specialized literature on the impacts of accessing poor quality water on human quality of life. There was also the survey and analysis of international rules of law under the aegis of the United Nations since its creation in 1945, of multilateral agreements on human rights and water, and Brazilian rules of law since the Federal Constitution of 1988, to discuss the guiding principles on human rights in the Constitution and in infra-constitutional norms, to identify the direct or indirect incorporation of international provisions related to the recognition of access to water as a fundamental human right.

Therefore, reference material such as books, periodicals, information and documents available in electronic format in the world wide web was collected, with the criteria of prioritizing information mainly related to human rights and the fundamental right to water. The data were then tabulated and analyzed.

\section{RESULTS AND DISCUSSION}

\subsection{Freshwaters in the world and in Brazil}

Concern over the present situation of freshwater availability is common in international society. According to official data of the United Nations (2011), water scarcity affects all continents and hinders the sustainability of natural resources, as well as social and economic development, affecting more than $40 \%$ of all people in the world, and 41 countries in hydric stress (ONU, 2015, p. 55).

The severe problem of water shortage in the world occurs due to "factors such as social inequality, lack of management and sustainable use of natural resources, population growth and pollution of water sources" (Garcia, 2014, p. 9). The vulnerability of people is of serious concern, and reflects the inexistence or ineffectiveness of public policies on sustainable access to drinking water. The supply of drinking water to the whole population must be on top of the priority agenda of public policies, since when not supplied the exercise of several fundamental human rights is precluded.

The supply of sufficient drinking water, or even the supply of non-potable water, involves serious human risks in terms of human health. People submitted to those situations suffer, directly or indirectly, several harmful consequences. The figures are alarming, mainly on water privation, either due to access or contact with poor quality water. Infant mortality directly related to access of poor water quality or lack of water is equally disturbing - about 1.5 million children under the age of five years; almost $90 \%$ of the about four billion yearly episodes of diarrhea are attributed to deficiencies in sanitary sewage system and provision of good quality water (Confalonieri et al., 2010). According to data from the United Nations Development Programme, about half the people in developing countries are affected by health problems due 
to water and sanitation, and this is the second leading cause of infant mortality in the world (ONU, 2006).

Although in global terms the number of people with access to treated water has increased considerably, representing 58\% of the world population, it was estimated that in 2015 about 663 million of people worldwide still use untreated sources of drinking water, including wells and water sources without protection, and also surface waters (ONU, 2015). This study advocates the provision of true universal access to treated water in sufficient, safe and acceptable ways, physically and economically accessible, with absolute respect to the right of life. Access to good quality water, after adequate treatment, will guarantee the maintenance of people's life.

Prüss-Üstün et al. (2008) estimate that about $10 \%$ of the global disease burden is due to poor quality water and deficiencies in the sanitation system. The relationship between water and human health occurs mainly as "a vehicle for microbial agents that cause gastroenteritis", especially due to fecal contamination or other infections such as leptospirosis; "as a vehicle for toxic agents", natural or of anthropic origin; "as a reservoir for disease vectors" such as mosquitoes that carry malaria and dengue fever, and intermediate hosts as snails; direct or indirect "physical impacts", as floods in populated areas or damage to food production (Confalonieri et al., 2010, p. 29).

It is unquestionable that water is the raw material for most human activities and is essential for life. For this reason, its priority use should be for human and animal consumption, as stated in the National Water Resources Policy. Having a large water supply as in Brazil does not guarantee good-quality water to the population, because it is geographically unequal. Water quantity and quality tend to worsen due to unhealthy practices and waste, such as inexistent and inefficient public policies to supply drinking water to the national population and improper sewage sanitation, which creates a favorable environment for the dissemination of several contaminants: microorganisms such as bacteria, viruses, and parasites, natural toxins, chemical products, pesticides, amongst others.

As a consequence of the availability or poor-quality water that damages human health, it is vital to discuss the right to the sustainable access to good-quality water in Brazil. The Brazilian state is a signatory of international treaties and a member of international bodies that recognize this fundamental human right, but did not explicitly state it in the Federal Constitution. However, the fact that it is not stated does not mean that Brazil lacks internal law in the same sense. The intention is to consolidate this fundamental right so that citizens can demand it in government discussion forums, as well as in the Judiciary in the case of inertia of the state regarding the obligation to guarantee sustainable access to drinking water for the people.

\subsection{International recognition of access to drinking water as a human right}

Human rights are funded in many international acts of the United Nation, such as the Universal Declaration of Human Rights; the International Covenant on Civil and Political Rights (ICCPR) in its First Optional Protocol; the International Covenant on Economic, Social and Cultural Rights (ICESCR), as well as the Second Optional Protocol of the ICCPR. These rights inherent to the nature of the human being, and their effective realization is indispensable to individual development.

These rights and guarantees seek respect for human dignity, with the establishment of minimal living conditions and the development of people's personalities (Moraes, 2006). The dignity of the human being is the compliance by the State and particular people "to the conditions of the human being, political, social, and professional innate to any individual and depends on the protection of fundamental rights and guarantees" (Mattar, 2010, p. 5).

Fundamental rights, as noted by Canotilho (1999, p. 517), involve the role of citizen's defense under two terms: 
[...] in a legal-objective term, rules competent to the public power, prohibiting, fundamentally their interference in the legal-individual sphere; they imply, in a legal-subjective term, the power to exert positively fundamental rights (positive freedom) and demand omission from the public powers to avoid detrimental attacks by them (negative freedom).

Sustainable access to potable water is absolutely essential for the maintenance of human life, and enables the regular development of people in all dimensions of their existence because it is closely related to the other fundamental human rights such as education, health, work, leisure, access to justice, exercise of private rights such as the right of property, as a consumer, and other fundamental human rights. These rights must be recognized and guaranteed by the State under the principles of respect, protection, and accomplishment, and must not be violated. It is the role of the State to promote and guarantee the recognized rights implicitly and explicitly determined in their domestic legal systems.

The United Nations has gradually evolved towards the recognition of water access as a human right. It is considered gradual because it is a construction where it is possible to identify in legal systems that do not directly address this subject, but guarantee the sustainable access to drinking water by linking it to other fundamental human rights, thereby promoting it until the United Nations directly and unequivocally regulates it as a fundamental right. According to data from the UN-Water Global Analysis and Assessment of Sanitation and Drinking-Water (UN, 2014), almost three quarters of the countries (70 of 94 that responded) recognize the human right to water in their Constitutions or other legislation. This is an expressive figure and demonstrates the efforts of United Nations member countries to follow international agreements.

The efforts of the United Nations can be identified in several international legal acts, direct and indirectly related to water, as will be seen next.

Although the constituent treaty of the United Nations, from 1945, does not mention the right to water, non-access to water in enough quantity and quality for the maintenance of life underlies the purposes described in the Article 55 of the Charter of the United Nations (Scanlon et al., 2004, p. 3).

The Universal Declaration of Human Rights, from 1948, in Article 3 determines the right to life. Without good quality water one cannot talk about the right to life, since it is an indispensable resource for its maintenance, and when it is contaminated it is a vehicle for several diseases. In addition, the Article 25 states the right to health and welfare, including food. Only with access to enough water of good quality it is possible to guarantee health and wellbeing to people.

The III Geneva Convention, of 1949, in Articles 20, 26, 29 and 46; the IV Geneva Convention, of 1949, in Articles 85, 89 and 127; the I Optional Protocol, of 1977, in Articles 54 and 55; and the II Optional Protocol, of 1977, in Articles 5 and 14, recognize directly the right to potable water to satisfy thirst (Scanlon et al., 2004, p. 35).

In 1966, there was the International Covenant on Economic, Social and Cultural Rights. Principle 11 recognizes "the right of every people for an adequate standard of living for himself and his family, including adequate food, clothing, and housing, as well as to a continuous improvement of his life conditions", combined with Principle 12, which recognizes that any person must enjoy the highest possible level of physical and mental health, and the state parties should take action to reduce infant mortality, improve all aspects of hygiene at work and in the environment, prevent and treat epidemics, endemic and professional diseases, and other actions. Through the access to potable water, and in sufficient quantity, people will be able to enjoy a better quality of life. This is also recognized by the International Covenant on Civil and Political Rights, also of 1966, which in Article 6 affirms that the right to life is inherent to the human being. 
The United Nations Conference on the Human Environment, which occurred in 1972 in Stockholm, was the first universal document on the environment. Although it did not specifically treat the water theme, it brought about the second principle that "The natural resources of the earth, including the air, water, land, flora and fauna and especially representative samples of natural ecosystems, must be safeguarded for the benefit of present and future generations through careful planning or management, as appropriate". The objective was to raise awareness among the States on the importance of promoting "the cleaning up of rivers in the areas of the most populated watersheds and combat marine pollution" (Setti et al., 2001, p. 171).

In the United Nations Water Conference, held in Mar del Plata in 1977, the Action Plan declares that "All peoples, whatever their stage of development and social and economic conditions, have the right to have access to drinking water in quantities and of a quality equal to their basic needs". According to Salman and McInerney-Lankford $(2004$, p. 8), this document advanced the universal recognition of water availability as essential to life and man's full development, either as an individual or as a society member.

The Convention on the Elimination of All Forms of Discrimination against Women, of 1979, besides establishing a set of goals to end discrimination against women, refers to water by guaranteeing the right "To enjoy adequate living conditions, particularly in relation to housing, sanitation, electricity and water supply, transport and communications" (Article 14).

The United Nations World Commission on Environment and Development in 1987 produced one of the most important environmental reports, called the Brundtland Report, with the presentation of the concept of sustainable development, which meets the needs of the present without compromising the capacity of future generations to meet their own needs. Sustainability must be considered one of the criteria to determine good practices to exercise the right to water.

The Convention on the Rights of the Child, of 1990, refers explicitly to the right to water amongst the measures to guarantee and protect the children's rights (Article 24, Section "c"), and according to Gleick $(1999$, p. 8) it is "the first explicit mention to the connection among resources, environmental conservation, and human health".

The recognition of the basic right of everyone to have access to clean water at an accessible price appears in Article 4 of the International Conference on Water and the Environment (Dublin Conference, 1992). Setti et al. (2001, p. 175) and highlights that "freshwater is a finite and vulnerable resource, essential for the conservation of life, maintenance of development and of the environment".

The United Nations Conference on Environment and Development, held in 1992, in Chapter 18 of Agenda 21 subscribed the Resolution of the Conference on Water, held in Mar del Plata, according to which all peoples have the right to access potable water, calling for the "commonly agreed assumption". The affirmation that all individuals have the right to an adequate standard of living for themselves and their families, including adequate food, clothing, housing, water, and sanitation, as recorded in the International Conference on Population and Development's (ICPD) Program of Action.

The Political Declaration of the World Conference on Sustainable Development, held in Johannesburg in 2002, establishes determinations through decisions on goals, timetables, and partnerships to accelerate access to basic requisites such as clean water, sanitation, energy, health care, food safety, and biodiversity protection.

The Convention on the Rights of Persons with Disabilities, 2006, defines the right of people to an adequate standard of living and establishes the obligation of the signatory states to assure "the equal access of people with disabilities to clean water services, and to assure the access to services, devices, and other support to specific needs of disability, adequate and at reasonable prices" (article 28 ). 
Besides several provisions in international agreements, it is still possible to identify in other international acts within the United Nations that consider the access to water as a fundamental right, such as in the Resolution 54/175, of 17 December 1999, relative to the right to development, where it affirms that for the total implementation of the right to development, among others, the rights to feeding and clean water are fundamental rights and their promotion is a moral imperative for national governments and countries of the international society (Article 12). The Resolution 55/196, of 20 December 2000, proclaimed the year 2003 the International Year of Freshwater.

In General Comment 15, 2002, of the Committee on Economic, Social and Cultural Rights relative to the Right to Water, the right to an adequate standard of living (Article 11) is identified, as well as the right to the highest attainable standard of health (Article 12). The Comment notes the obligations of the member states to ensure the right and defines which actions would constitute a violation. A particular point of attention is described in Article I.1, which establishes that "The human right to water is indispensable for leading a life in human dignity.

It is a prerequisite for the realization of other human rights".

Resolution 58/217, of 23 December 2003, proclaimed the International Decade for Action, "Water for Life", (2005-2015).

The 2007 Report of the Office of the United Nations High Commissioner for Human Rights (OHCHR) regards the scope and content of obligations on human rights related to the equitable access to drinking water and sanitation that impose international human rights instruments. In the sequence of Decision 2/104 of the Human Rights Council, the report of the High Commissioner for Human Rights states that the time has come to consider access to safe potable water a fundamental human right, defining the right to isonomic and non-discriminatory access to enough quantity of potable water per person and for other domestic uses, to assure life and health.

In the Resolutions of the Human Rights Council 1/22, of 28 March 2008, and 12/8, of 01 October 2009, relative to the human right to drinking water and sanitation, the Human Rights Council in an innovative way recognizes that the States have the obligation to resolve and end discrimination in terms of access to water, and asks them to resolve efficiently the inequalities of this matter. In 2009, the Resolution 64/198, of 21 December 2009, analyzes the first half of the period of activities of the International Decade for Action, "Water for Life". The Resolution 15/9 of the Human Rights Council, 2010, and affirms that the right to water is part of existing international law and confirms that this right is legally mandatory for the States. It invites the States to develop adequate tools and mechanisms to gradually attain the full implementation of the obligations in terms of human rights related with access to safe drinking water, including in unserved or insufficiently served areas.

After this legal evolution at an international level, resulting from in-depth debates, the United Nations passed Resolution 64/292, of 03 August 2010, and recognized the right to drinking water as an essential human right for the full enjoyment of life and human rights. This United Nations Resolution is not limited to the recognition of access to drinking water as a human right, but advances to recognize that this right is essential for the full enjoyment of life and all human rights. There was a call for the subjects of public international law to provide financial resources and to increase the capacity to transfer technology through international assistance and cooperation, especially to developing countries, to intensify the efforts to provide all the populations economic access to drinking water.

Penã (2016), when referring to the Latin America and Caribbean regions, states that it is more realistic for the conditions of the regions to establish an objective of universal access to services of drinking water, considering household connections, at least in the cities. The author highlights Agenda 2030 for the sustainable development, adopted by the United Nations 
General Assembly in 2015, that expressly established the universalization of drinking water services until 2030, as well as goals related to the control of contamination and treatment of residuary water, efficiency in water use, integrated management of water resources and ecosystem protections, amongst others (Peña, 2016, p. 30).

Although it is an international law devoid of sanctions, classified as Soft Law, as normally occurs within this domain, it represents a significant advance of human rights and, since access to water is intimately linked to life, health, and dignity, it should be considered implicit within these human rights. The enjoyment of the other human rights is only possible through a balanced environment, especially access to good quality water. It is a direct obligation of sovereign States to promote and protect human rights, universally, indivisibly, interrelatedly and interlaced, and should be treated in a global, just, and fair way.

The human right to water refers to the right of all citizens to: a) supply of water per person in a sufficient and continuous way for personal and domestic use, serving in general for drinking, personal sanitation, and for domestic use such as feeding and cleaning; b) safe personal and domestic use, free of microorganisms, chemical substances, and radiological hazards that threaten the human health; c) access to water of acceptable standards for personal or domestic use regarding color, smell, and flavor; d) physically accessible, in other words, to be possible to access water with the characteristics highlighted above as nearly as possible; e) access water at an accessible price to avoid social discrimination.

Brazil belongs to the the United Nations and must respect its determinations, either the international treaties or the normative acts of the institutions of this international organization. Therefore, it must have total respect for matters settled at an international level, with the duty to internalize these legal determinations that consider access to water a human right.

\subsection{Recognition of access to drinking water as a human right in Brazil}

The international agreements on human rights have an important role in the judiciary administration of the water issue, and must equate the constitutional provisions with legal impacts on the national infra-constitutional law.

For the effectuation of the right to drinking water in the Brazil, all government levels must develop consistent measures to guarantee access to water in sufficient quantity and adequate quality. If this right is not effected in an universal way, there will be a denial of justice related to human rights in general, and especially in water issues.

The right to access water is closely connected to other human rights, such as the rights to life, health, education, dignity and work. However, for its effective protection, it is recommended that the laws of sovereign States explicitly recognize it in order to guarantee the access to sufficient quantities of potable water for personal and domestic use, personal sanitation, washing clothes, preparing food, personal and domestic hygiene, and access to sanitation in general ${ }^{1}$ to protect the quality of drinking water supply and other multiple use of water resources.

\footnotetext{
${ }^{1}$ Basic sanitation is considered, according to Law 11,445/07, the set of services, infrastructure, and operational installations for drinking water supply, sewage sanitation, urban cleaning, and management of solid residuals, drainage and management of urban stormwater.
} 
It is impossible to find a specific provision in the 1988 Federal Constitution that guarantees the right to drinking water as a fundamental human right. However, several constitutional provisions deal with the theme of the water, such as Article 21, Subsection XX, which determines that it is the responsibility of the Union to establish directives for the basic sanitation. Article 23, Subsection VI, determines that it is the common responsibility of all bodies of the federation to protect the environment and combat pollution in all of its forms, and to promote programs to improve basic sanitation conditions (Article 23, Subsection IX). It is the responsibility of the Unified Health System (SUS) to participate in the formulation of the policy and execution of basic sanitation actions (Article 200, Subsection IV). The responsibility to legislate on water issues is reserved to the Union (Article 22, Subsection IV), not excluding the States, which can be authorized by declaratory statute (Article 22, sole paragraph). Municipalities may legislate on local interest issues and supplement state or federal legislation when appropriate (Article 30, Subsections I and II).

When the specific catalogue of fundamental rights and warranties is examined, the protection of the right to access drinking water is not subscribed in the Constitution, at least in an explicit way. Therefore, the erroneous conclusion could be reached that all international treaties and norms signed by Brazil cannot be enforced. It is exactly the contrary, since the 1988 Federal Constitution, Article 5, $\S 2$, establishes that "The rights and warranties expressed in this Constitution do not exclude others arising from the regime and principles adopted by it, or from the international treaties that the Federal Republic of Brazil is participant".

Thus, the legal grounds for the recognition of the access to drinking water as a fundamental human right in Brazil are:

i) since the Brazilian state adhered to the international treaties mentioned before, as well as being a member State of the United Nations, which in legal acts of the international organization equally establish this human right as fundamental;

ii) according to the principle of non-legal typification of fundamental rights (Pes, 2010) those subscribed in the Constitution and other formal sources of Law can be considered fundamental human rights. In this way, the principles adopted by the Constitution and international treaties on human rights, recognized by the Brazilian state, should also be considered. This tenet applies not only to the fundamental human rights explicitly specified in the Constitution, but also considers as fundamental the ones subscribed in other sources of Law and a "wider perspective of the material Constitution" (Cunha Junior, 2008, p. 617). This tenet is founded in the Federal Constitution itself, in the second paragraph of Article 5, when considering the constitutional set-up as merely exemplifying, not excluding future ones, including those from international treaties and other formal sources, as is the case with the access to drinking water;

iii) that in infra-constitutional texts drinking water is treated as essential for human life.

Although the access to drinking water in sufficient quantity and adequate quality for the maintenance of life is not included in the constitutional text, public managers and national courts must adopt with no restrictions the principle of non-legal typification of the fundamental right, together with the principle of personal human dignity (Article 1, Subsection III) in their decisions, to avoid people being deprived of drinking water, independently of economic interests, as happens when there is a shortage in water supply, or political agents postpone the provision of sanitation services essential to people. It is argued that the economic conditions of people cannot be an obstacle to the enjoyment of this fundamental right, not even due to claims by the public agents of lack of funding resources for the supply of good quality water, and in enough quantity for the essential human conditions. 
Besides applying the principle of non-legal typification of fundamental rights and the principle of personal human dignity, public managers and judges must extensively interpret some infra-constitutional judicial orders within the so-called normative system of Bobbio (1997), recognizing the access to water as a fundamental human right.

The Brazilian state has infra-constitutional laws in this sense, such as the Brazilian National Water Policy (Law 9,433/1997) which establishes that water is a public asset for collective use by the people. Water does not belong to the government, not even to particular people; it is a public asset so that identifiable appropriation is not accepted, since it is a fundamental human right, characterized by inalienability and non-waiver of rights (Irigaray, 2003). Water law establishes still that in shortage situations, the priority use is for human consumption to meet essential needs, and for animal consumption (Article 1).

The law that determines the national directives for basic sanitation and for the federal policy on basic sanitation (Law 11,445/20017) established that public services of basic sanitation will be provided based, among other things, on the principle of universal access (Augusto et al., 2012), which means the gradual extension of access to all occupied homes. The provision of these services must meet minimum quality requirements such as regularity and continuity (Article 43). Universal access, in a regular and continuous way, can be understood as the recognition by Brazil of all international legal acts in this sense. ${ }^{2}$

According to government data, "access to the general network, or water well, or channelized spring increased in urban houses from 95\% to 97\% between 2000 and 201 in Brazil" (IPEA, 2016, p. 102). Universal access is closer in the Southeast (99\%), South (99\%) and Mid-West (98\%), whereas in the Northeast it reached $94 \%$ and in the North $92 \%$ of the homes in 2013 (IPEA, 2016, p. 103).

In general terms, the Brazilian Institute of Geography and Statistics (IBGE, 2013, p. 15) recorded in 2012 that $85.4 \%$ of Brazilian houses were attended by a general network ${ }^{3}$ of water supply, equivalent to 53.6 million of house units. According to the National Survey on Basic Sanitation, which occurred in $2008,87 \%$ of the municipalities delivered completely treated water, although in $6.2 \%$ water was partially treated and in $6.6 \%$ there was no treatment at all (IBGE, 2013, p. 19). This national survey pointed that in Brazil the largest volume of delivered treated water $(69.2 \%$ ) occurs in the conventional treatment process, most used in the Northeast, Southeast, and Southern regions. In the Northern region, conventional treatment is done on less than half $(40.8 \%)$ of the delivered water that receives any kind of treatment, and about $31.7 \%$ of water treatment is done by unconventional processes and $27.4 \%$ water treatment is done only by simple disinfection (IBGE, 2011, p. 27). This study argues that the universal access to drinking water in sufficient quantity and adequate quality is a fundamental human right, and thus it is unacceptable that a citizen be deprived of water in quantity, quality, and in essential form for life maintenance and the exercise of other fundamental human rights.

\footnotetext{
2 A major instrument of the basic sanitation policy, due to Law 11.445/2007 and Resolution 7..,217/2010, is the National Plan for Basic Sanitation - Plansab (Resolution 8.141/2013 and Interministerial Ordinance 571/2013).

${ }^{3}$ General network is used when the residence is served by water from a general distribution network, channelized for the residence or, at least, for the plot or property where it is located.
} 
Law 10,257/2001 establishes legal general directives of urban policies, and aims to plan the full development of the social functions of city and urban property. Among the general directives, Article 2, Subsection I describes the "guarantee of the right to sustainable cities, understood as the right to urban land, to housing, to environmental sanitation, to urban infrastructure, to public transport and services, to work and to leisure, for the present and future generations". Therefore, a city can only be considered sustainable when it fulfills its social functions, when there is respect for the right to sanitation services.

Law 11,445/2007 recognizes as elements of basic sanitation the set of services, infrastructure, and operational installations of "drinking water supply: consisting of the activities, infrastructure, and installations necessary to the public supply of drinking water, from water abstraction to building connections and respective measurement instruments" (Article $3^{\text {rd }}$, Subsection I, Clause "a"). From the right to access to drinking water comes the right of participation and information access, described in Articles 9, Subsection VI; 11, Subsection IV and $\S 3^{\text {rd }} ; 26 ; 27 ; 47 ; 51$ and 53 ), the latter referring to the National Information System on Sanitation (SINISA).

In relation to accountability to the citizens, the national law predicts the validity of the contracts of sanitation public services conditioned, among other things, to "III - the existence of regulation clauses that predict the means to compliance with the directives of the present Law, including the designation of the inspection and regulation entity;" combined with $\S 2^{\text {nd }}$, Subsection V; $\S 3^{\circ}$ (both from Article 11), and Article 12.

Regarding the access to good-quality water, Law 11.445/2007 determines that these public services will have economical-financial sustainability being assured "wherever possible, through remuneration from service collection" (Article 29). Its first paragraph determines that for basic sanitation services, the following directives for the institution of rates, public prices, and charges of "I - priority for the attendance of the essential functions related to public health;" and "II - expansion of access for low-income citizens and localities to the services;". For users and localities with no ability to pay or enough economic scale compatible with the full cost of the services, paragraph 2 of Article 29 of this Law considers the possibility of adopting tax and non-tax subsidies. This latter provision should be understood as a guarantee for the supply of drinking water for low-income people, since one of the factors considered for the establishment of values to be collected for the service of treated water supply is the minimum amount of consumption or service usage for social services such as the preservation of public health, adequate service for low-income users, and the payment capacity of the consumers (Subsections III and VI of Article 30).

The recognition of the fundamentality of the right to drinking water is clear when the National Policy for Sanitation recognizes that at the moment of the interruption or restriction of water supply due to non-payment of the tariff, "in healthcare facilities, educational institutions, collective internment institutions, and low-income residential users that benefit from social taxes must obey timescales and criteria that preserve minimum conditions for the maintenance of health of the people concerned." (Article 40, $\S 3$ ). It is the right to the minimum necessary for the maintenance of people's health in these situations, and the Law mentions those devoid of financial resources, namely low-income users, equally benefited by the minimum amount of water essential for the quality of life. Although there are well-delimited situations that warrant this necessary minimum, it is defended here that for the full exercise of this fundamental human right, this necessary minimum amount of water must be extended to all people, regardless of social and economic conditions.

Since the supply of drinking water is a paid public service, in case of non-payment by the consumer, he or she must not be ridiculed or exposed to shameful situations or threatens (Article 42, Law 8.078/1990). Also, because access to water is a fundamental human right, it is noted 
here that the shutting down of water services is prohibited for consumers that are unable to pay for the services, since there can be no discrimination due to their economic situation.

Besides the right to the minimum amount for the existence of life, this service provision must follow minimum quality standards, including regularity, continuity, and those associated with the products offered, the service to users, and to operational conditions and systems maintenance, according to regulation and contractual norms. These minimum standards for water potability are defined by the Union (Article 43).

\section{FINAL CONSIDERATIONS}

The amount of easily accessed freshwater is absolutely inferior to the total amount of water available in the planet. The difficulty of accessing freshwater worsened by the exponential increase of the population and by unsustainable usage practices, leading to shortages in many countries.

Although Brazil is favored by a large quantity of freshwater, the problem is in its geographical location, resulting in water shortages that, added to the fact that there are few public policies for the provision of drinking water, aggravate the situation of the national population, with negative impacts to the lives of these citizens. Since they have no sustainable access to drinking water, their fundamental rights are affected, directly and indirectly, with respect to life and dignity.

Access to water in sufficient quantity and quality, and considered sustainable, is vital and assures the quality of life and health of the population. In this sense, United Nations evolved to recognize as a human right, which is identified in several international acts and agreements, until the direct and unquestionable recognition of the access to drinking water as a human right, essential for the full enjoyment of life and all human rights.

In the case of Brazil, the international norms are reflected in the Law. However, they do not appear explicitly in the Federal Constitution, but are subscribed in other formal sources of law. The principle of non-legal typification of fundamental human rights can and must be used at this moment in the absence of an express constitutional provision. Therefore, the public authorities cannot evade the obligation to provide water in sufficient quantity and quality to all people; otherwise, they must be considered to be not in compliance with the international legal framework of the United Nations. Further, internally the authorities must expressly authorize these fundamental rights, intimately and directly linked to the right to life, and to the exercise of all other fundamental rights.

Since the authorities cannot evade the obligation to provide sustainable access to drinking water to the people, subscribed in infra-constitutional norms, they must make every effort to offer water in enough quantity and adequate quality to all people. This is an immediate need because access to poor-quality water or in insufficient amounts directly affects the life, health, and dignity of people. This is the core of the recognition of this right as fundamental to humans, without excluding other linkages.

The judiciary can mandate the right to the access of drinking water by the coercive power exerted by the Justice authorities, when facing situations of denial of rights by authorities due to insufficient economic resources for supply in sufficient quantity and quality, or even in specific situations of consumers devoid of financial resources for the payment for the public service of the bare minimum amount of water.

\section{ACKNOWLEDGEMENTS}

To the Programa de Pós-Graduação em Ciências Ambientais (PPGCAm/UFSCar), the research group CNPq/UFSCar "Novos Direitos" and grant \#2016/14163-7, São Paulo Research Foundation (FAPESP). 


\section{REFERENCES}

AGÊNCIA NACIONAL DE ÁGUAS - ANA (Brasil). Atlas Brasil: abastecimento urbano de água: panorama nacional. Brasília: ANA, Engecorps/Cobrape, 2010. 72p.

AGÊNCIA NACIONAL DE ÁGUAS - ANA (Brasil). Conjuntura dos recursos hídricos: informe 2016. Brasília, 2016. 95p.

AUGUSTO, L. G. S.; GURGEL, I. G. D.; CÂMARA NETO, H. F.; MELO, C. H.; COSTA, A. M. O contexto global e nacional frente aos desafios do acesso adequado à água para consumo humano. Ciência \& saúde coletiva, v. 17, n. 6, p. 1511-1522, 2012. http://dx.doi.org/10.1590/S1413-81232012000600015

BICUDO, C. E. M.; TUNDISI, J. G.; SCHEUENSTUHL, M. C. B. (Orgs.). Águas do Brasil: análises estratégicas. São Paulo: Instituto de Botânica, 2010, 224 p.

BOBBIO, N. Teoria do ordenamento jurídico. Brasília: Editora UNB, 1997. 184 p.

BRASIL. Ministério das Cidades. Secretaria Nacional de Saneamento Ambiental - SNSA. Sistema Nacional de Informações sobre Saneamento: diagnóstico dos serviços de água e esgotos. 2014. Brasília: SNSA/MCIDADES, 2016. 212 p.

CANOTILHO, J. J. G. Direito constitucional e teoria da constituição. 3. ed. Coimbra: Almedina, 1999.

CONFALONIERI, U.; HELLER, L.; SANDRA, A. Água e saúde aspectos globais e nacionais. In: BICUDO, C. E. de M.; TUNDISI, J. G.; SCHEUENSTUHL, M. C. B. (Orgs.). Águas do Brasil: análises estratégicas. São Paulo: Instituto de Botânica, 2010. p. 2738

CORTES, P. L.; TORRENTE, M.; PINTO, A. P. A.; RUIZ, M. S.; DIAS, A. J. G.; RODRIGUES, R. Crise de abastecimento de água em São Paulo e falta de planejamento estratégico. Estudos Avançados, v. 29, n. 84, p. 7-26, 2015. http://dx.doi.org/10.1590/S0103-40142015000200002

CUNHA JUNIOR, D. Curso de direito constitucional. Salvador: Podivm, 2008. 1.115 p.

FEACHEM, R. G.; BRADLEY, D. J.; GARELICK, H.; MARA, D. D. Sanitation and disease: health aspects of excreta and wastewater management. Chichester: John Wiley, 1983.

GALLI, C. S.; ABE, D. S. Disponibilidade, poluição e eutrofização das águas. In: BICUDO, C. E. M.; TUNDISI, J. G.; SCHEUENSTUHL, M. C. B. (Orgs.). Águas do Brasil: análises estratégicas. São Paulo: Instituto de Botânica, 2010. p. 165-174.

GARCIA, L. A. A viabilidade de implantação do sistema de reutilização da água pluvial para fins não potáveis no âmbito da academia bombeiro militar do estado de Goiás. 2014. 30 p. Monografia (Formação de Oficiais) - Academia Bombeiro Militar, Goiânia, 2014.

GLEICK, P. The human right to water. Water Policy, v. 1, n. 5, p. 487-503, 1999. https://doi.org/10.1016/S1366-7017(99)00008-2

GLEICK, P. The world's water. 2000-2001. Report on Freshwater Resources. Island Press, 2000. 315p.

HOWARD, G.; BARTRAM, J. Domestic water quantity, service and Health. Genebra: WHO, 2003. 39p. 
INSTITUTO BRASILEIRO DE GEOGRAFIA E ESTATÍSTICA - IBGE. Censo de Saneamento 2011. Rio de Janeiro, 2011. 268p.

INSTITUTO BRASILEIRO DE GEOGRAFIA E ESTATÍSTICA - IBGE. Cobertura de saneamento básico no Brasil segundo Censo Demográfico, PNAD e PNSB. Rio de Janeiro, 2013.

INSTITUTO DE PESQUISA ECONÔMICA APLICADA - IPEA. Relatório brasileiro para o Habitat III. Brasília: ConCidades, IPEA, 2016. 139 p

IRIGARAY, C. T. H. Água: um direito fundamental ou uma mercadoria? In: BENJAMIN, A. H. (Org.). Congresso Internacional de direito Ambiental: direito, água e vida. São Paulo: Imprensa Oficial, 2003. v. 1.

MATTAR, J. J. M. A dignidade da pessoa humana como fundamento do Estado Democrático de Direito. Rede - Revista Eletrônica Direito do Estado, n. 23, 2010.

MORAES, A. Direitos humanos fundamentais: teoria geral, comentários aos art. $1^{\circ}$ a $5^{\circ}$ da Constituição da República Federativa do Brasil, doutrina e jurisprudência. 7. ed. São Paulo: Atlas, 2006.

ORGANIZAÇÃO DAS NAÇÕES UNIDAS - ONU. Programa das Nações Unidas para o Desenvolvimento (PNUD). Relatório do Desenvolvimento Humano 2006. A água para lá da escassez: poder, pobreza e crise mundial da água. New York: PNUD, 2006.

ORGANIZAÇÃO DAS NAÇÕES UNIDAS - ONU. Objetivos de desarollo del milênio. Informe de 2015. New York: ONU. 75p.

OLIVEIRA, C. M.; AMARANTE JUNIOR, O. P. Direito internacional das águas doces. São Carlos: RiMa, 2009. 163 p.

PEÑA, H. Desafíos de la seguridad hídrica en América Latina y el Caribe. Comissão Econômica para América Latina e o Caribe (CEPAL). Santiago: ONU, 2016. 57 p.

PES, J. H. F. A constitucionalização de direitos humanos elencados em tratados. Ijuí: Unijuí, 2010. 168 p.

PRÜSS-ÜSTÜN, A.; BOS, R.; GORE, F.; BARTRAN, J. Safer water, better health: costs, benefits and sustainability of interventions to protect and promote health. Geneva: WHO, 2008, 60p.

RAZZOLINI, M. T. P.; GÜNTHER, W. M. R. Impactos na saúde das deficiências de acesso a água. Saude e Sociedade, v. 17, n. 1, p. 21-32, 2008. http://dx.doi.org/10.1590/S010412902008000100003

SALMAN, M. A.; MCINERNEY-LANKDORD, S. The human right to water: legal and policy dimensions. Law, Justice and Development Series. Washington, D.C.: The World Bank, 2004. 182p.

SCANLON, J.; CASSAR, A.; NEMES, N. Water as a Human Right? IUCN Environmental law and Policy. Paper $n^{\circ}$. 51. Gland; Cambridge: IUCN The World Conservation Union, 2004.

SETTI, A. A.; LIMA, J. E. F.; CHAVES, A. G. M.; PEREIRA, I. C. Introdução ao gerenciamento de recursos hídricos. 2. ed. Brasília: Agência Nacional de Energia Elétrica; Agência Nacional de Águas, 2001. 
TUCCI, C. E. M.; HESPANHOL, I.; NETTO, O. M. C. Gestão da água no Brasil. Brasília: UNESCO, 2001. 156p.

TUNDISI, J. G. Recursos hídricos no futuro: problemas e soluções. Estudos Avançados, São Paulo, v. 22, n. 63, p. 7-16, 2008. http://dx.doi.org/10.1590/S0103-40142008000200002

UNITED NATIONS - UN. UN-water global analysis and assessment of sanitation and drinking-water (Glaas) 2014 report: investing in water and sanitation: increasing access, reducing inequalities. Genebra: WHO, 2014. 108p.

WILLAARTS, B.; GARRIDO, A.; LLAMAS, M. R. Water for food security and well-being in Latin America and the Caribbean. Social and environmental implications for a globalized economy. Routledge: Fundación Botín, 2014. 